\title{
I, The World, The Devil and The Flesh: Manplan, Civilia and H. de C. Hastings
}

\section{Erdem Erten}

\section{Introduction}

A Facebook group page set up in 2008 exclaims: 'Nuneaton's Judkins Site should have Civilia Built Not hazardous waste!' The group making this appeal was campaigning against a controversial reclamation plant for contaminated soil to be located in a former quarry and demanded instead the realisation of another project for the site which they described as 'Civilia': a revolutionary concept of a totally new environment... conceived by an award-winning architect writing under the pseudonym Ivor de Wolfe. ${ }^{1}$

The journalist and the thirty nine members of the Facebook group of protestors can be excused for assuming that $\mathrm{H}$. de $\mathrm{C}$. Hastings, the real Ivor de Wolfe (or, on this occasion, de Wofle) was an architect. Although Hastings attended the Bartlett School of Architecture after the end of the First World War, he never qualified, and his preference for pseudonyms has continued to mask his achievement. Even so, his vision for Civilia, rising like an Italian hill town in concrete from the post-industrial wasteland and canals of the Midlands, was evidently so captivating and enduring that the local Heartland Evening News did not care to research its origins more thoroughly for the article of July $31^{\text {st }}, 2008$.

Civilia was the swansong of $\mathrm{H}$. de $\mathrm{C}$. Hastings's editorial reign at The Architectural Review (AR hereafter) which started in 1927 and ended in 1973. In 1971, the year of Civilia's publication, first as a special issue and later as a book, Hastings was awarded the Royal Gold Medal for Architecture in recognition
Department of Architecture, Izmir Institute of Technology, Turkey

of his editing and publishing activities. Having been an early enthusiast for the Modern Movement he ensured that the $A R$ sustained a lively debate about what it meant. For Hastings, the cultural issues around Modernism were paramount, especially its relationship to national history and the way the environment both looked and functioned.

Hubert de Cronin Hastings (1902-1986) was the second son of the Hastings family. Christened Robert Seymour, his father later changed his name to the more patrician Hubert de Cronin-de Cronin after a Huguenot grandmother. He graduated from Berkhamsted, a famous public school, where the headmaster was the novelist Graham Greene's father. In 1918 he started working for the Architectural Press which was co-owned by his father, attending the Slade School of Art and the Bartlett School of Architecture at University College, London for a basic visual education. ${ }^{2}$

In the years after 1945, Hastings, working with an editorial board that combined his senior staff and trusted allies such as Hugh Casson and Osbert Lancaster, gained in confidence. He made the magazine a more explicitly campaigning vehicle, first for a form of visual re-education and then for a combination of criticism of unimaginative forms of postwar reconstruction and conceptual proposals for doing it better. Under the rubric of Townscape the human and environmental cost of modernism's failures was shown to the relevant professions, politicians and the public, while offering a different way of designing urban spaces. Hastings recruited 
I, The World, The Devil and The Flesh: Manplan, Civilia and $\mathrm{H}$. de C. Hastings Erdem Erten

Figure 1. Hastings in front of his converted Rolls Royce during one of his countryside travels (courtesy of Priscilla Hastings).

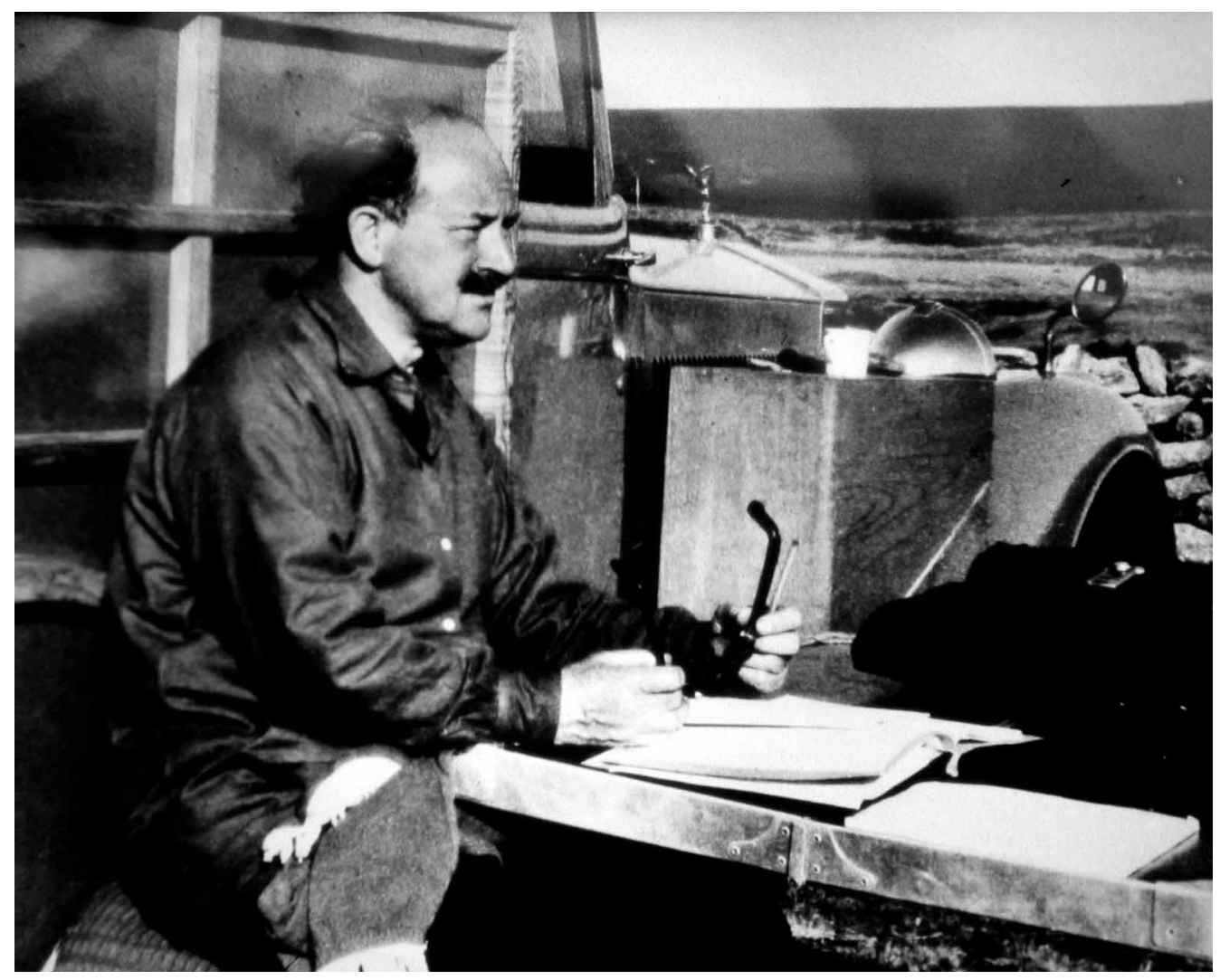

writers who left their mark on architectural culture by their ability to see this wider social and artistic field. Hailed by his colleagues for having 'injected fire' into $A R$ with his unceasing experimentation towards a radical and innovative visual layout, ${ }^{3}$ the outward appearance of the press impresario conceals the reality of a self-effacing, reclusive, mercur- ial and frequently irascible personality. The mind and motivation of the man who ran the periodical for forty six consecutive years still remain largely hidden, as his nickname, bestowed by John Betjeman, 'Obscurity', implies (Fig. 1).

While Hastings's role in the development of architectural discourse has become recognised in recent 
years, it is still not thoroughly understood. This paper aims to provide insight into Hastings's worldview as reflected in his unpublished manuscript The Unnatural History of Man and the two major campaigns of the AR, Manplan (1969) and Civilia (1971), as its most direct manifestations, undertaken only a few years before Hastings retired from architectural journalism. My intention here is not to discuss the text as the recently discovered masterpiece of an unknown genius, but as a key to understanding the motivation behind the seemingly disparate post-war campaigns of the $A R$.

\section{Hastings and The Unnatural History of Man}

Among Hastings's papers are the scattered partial drafts for a book, The Unnatural History of Man, on which he worked continuously from the 1940s to the late $1950 \mathrm{~s}^{4}{ }^{4}$ It was finally published in a reduced version entitled The Alternative Society in 1980. Running to over 880 pages, the full text was intended as a reformist manifesto, coming from the hand of an amateur who wanted his voice to be heard. While at the Slade, Hastings absorbed the doctrine of 'significant form', coined by Clive Bell in 1914. This critical method was largely founded on the necessity of educated taste, for 'significant form' was capable of arousing a peculiar sense of emotion only in those who had trained aesthetic sensibilities. Although Bell promoted abstract modern art within the Bloomsbury circle, his writing carried echoes of associationism, as advocated more than a century before by Archibald Allison and Richard Payne Knight. ${ }^{5}$ Hastings's text shows his predilection for an art of revelation in preference to an art of technique, especially characterised by William Blake's opposition to Sir Joshua Reynolds's consolidation of a mainstream classical tradition. He believed these precursors could be enlisted in support of an alternative vision for modern art and architecture, as part of his project in promoting Townscape.

Hastings's manuscript and the 1980 published version shared a central message: Western civilisation faced 'a bottomless inanity', ${ }^{6}$ a state of paranoid despair due to the threat of nuclear mass destruction. The British could, and should, assume a pioneering role to stop the approaching disaster before it destroyed the planet and, with it, human civilisation. It was written in response to the diminishing role of Britain as a world power and the dramatic change in its social and cultural structure. The post-war economy was slow to recover in the 1950s and, even in the age of pop and the rise of mass culture, it was fragile. By the late 1960s it was becoming clear that Britain had lost its former imperial role while the increasing influence of the United States on British culture had disturbed some British intellectuals between the wars who continued to stimulate the search for a valid independent way of life. Others, notably Hastings's prominent young assistant editor Reyner Banham, embraced America, putting British cultural identity under scrutiny as they did so.

The manuscript starts with a provocative depiction of the human condition in the face of the nuclear threat. Hastings points to the contradiction that while angst prevailed with the intellectuals among the 'New Elizabethans', the promise of a better future was fed to wider society through advo- 
cates of science and technology as the only agents of progress. ${ }^{7}$ The reign of specialists and experts in the administration of society was the real problem that Western civilisation had to address:

A new kind of dilemma, not knowing why things have gone wrong. They went wrong in the seventeenth century because mammon stalked up and down the land, in the eighteenth because privilege, superstition and taboo prevented the free play of reason, in the nineteenth because vested interests obstructed the progress of science. In the twentieth however, all the great abuses have vanished, together with our sense of sin, and science sits enthroned and there's next to nothing to put it right, yet here we stand... in front of a guided missile. . . Above all there is the modern fashion for specialization which sternly discourages public discussion except by experts. . . No one is to speculate about 'life' any more, the experts because they do not deign, the amateurs because they do not dare. ${ }^{8}$

For Hastings, humanity needed a utopian impulse, a new comprehensive ideological directive, to initiate what he called a 'collective come-back' before an holistic vision of life was irrecoverably lost. 'The British [had] always been incurably Messianic' he contended, and British insularity and the experience of the Industrial Revolution could help them overcome the turn of history initiated by the Cold War division. ${ }^{9}$ He claimed that in the seventeenth century Britain created a genuine opportunity to establish a model society of freedom: the realisation of a New Jerusalem. The British Civil War, which he called the 'Cromwellian revolution', was in Hastings's eyes the real birth of the modern world bringing forward the Industrial Revolution as well as British Romanticism. These two historically significant developments proved that it was possible simultaneously embrace the ideal of scientific and technological progress while still maintaining the priority of emotion over reason. According to Hastings, a revolution in the twentieth century had to aim at transforming human nature instead of the economic system. Idealising the Puritan revolution, he argued that the example of Cromwell could help to formulate a pluralistic democracy, one that would not only safeguard the welfare of every individual but also that of the natural environment.

The call for radical reform in Hastings's manuscript parallels the editorial manifesto that revealed the $A R$ 's post-war programme, entitled 'The Second Half Century' which signalled a future of intense campaigning. It opened with the lines 'Then Purg'd with euphrasy and rue/ The visual nerve, for he had much to see' from Milton's Paradise Lost. ${ }^{10}$ These lines refer to the scene when the future of mankind is revealed to Adam after his vision was cleansed. Post-war reconstruction was invested not only with the hope of recovery from unprecedented destruction but also the modern subject's salvation by means of a cultural programme of 'visual re-education', equivalent to Adam's cleansing experience.

Hastings saw himself as a genuine Tory, not a classical conservative as one would understand today but one who subscribed to a paternal socialism, which the conservatives defined in the 1930s, and was influenced by a liberalism defined in the thought of the historian and political theorist 
Ernest Barker (1874-1960). ${ }^{11}$ From the early 1940s to the late 1950s, Barker rose to become the main spokesman of English character, supported by the historians A. L. Rowse and G. M. Trevelyan. These thinkers opposed a slide towards social engineering, being especially against the growing power of the state and its centralised power apparatuses during the Labour administration of Clement Attlee from 1945 to 1951 . They found the emerging trend to specialisation insensitive 'to existing political and cultural traditions and political insights afforded by classical learning' which Hastings supported. ${ }^{12}$ Barker defended an idea of England securely anchored in Establishment institutions and practices, and a 'gentlemanly' ideal of government based upon liberal learning rather than trained expertise. Hastings's manifesto was highly influenced by Barker's views in its reconfiguration of the role of the State, the cultural elites and the nebulous category of citizens for a new social order. $^{13}$

Although he advocated mostly higher middleclass and aristocratic values, Barker also believed that it was not only these classes but also 'the simple tastes of the mass of people' that contributed to Englishness as he understood it. He saw wisdom in the daily rituals and traditions of the lower classes and believed that English culture had to be understood as an amalgam of their values as well as those of the higher ranks of society. Englishness, nevertheless, had three cultural 'constants: 1.The centrality of the gentleman, with its intimate connection to 2. the cult of the amateur, and to 3. the voluntary habit of association in British society seen in the role of groups of active citizens'. In
'The Unnatural History of Man' Hastings not only advocated similar ideals, such as the centrality of the gentleman for the new society and the role of humanities in education, he fashioned himself after the amateur gentleman who had no professional training with reference to the several disciplines his manuscript dealt with: such as sociology, psychology, philosophy, urban planning and history.

The threat that expertise might shut off citizens from public life was one that the $A R$ highlighted during the war. ${ }^{14}$ Hastings believed that the success of the $A R^{\prime}$ 's campaigns would set an example and renew faith in the spirit of the amateur. In parallel, the $A R^{\prime}$ 's post-war programme for 'visual re-education' would encompass a broad cultural range, from popular and local arts to the reappraisal of the vernacular to high art. ${ }^{15}$ Hastings did not care about the professional credentials of the authors he recruited for the $A R$, but valued them for the quality and strength of their work. It is no surprise that those who were not necessarily architects, like John Betjeman and lan Nairn, were given their first opportunities by him, while others frequently contributed to the $A R$ and offered readers a view of architecture in a larger cultural context.

Regarding the Industrial Revolution and British Romanticism as direct consequences of the British Civil War and referring to it as a revolution was not uncommon at the time Hastings was writing. Since the 1930s a new historiography developed which 'viewed the Civil War as a pivotal movement in the creation of the English tradition, as a decisive phase in socialist theoretical development, and as a revolution, not an interregnum. ${ }^{16}$ For Marxist 
historians such as Edward Palmer Thompson, Christopher Hill and Richard Hoggart, and later Raymond Williams, the Civil War conjured up the vision of a 'co-operative social commonwealth' in which the 'iniquity of class' would be removed. ${ }^{17}$ They were interested in the Romantic tradition, seeing in its opposition to liberalism, utilitarianism and laissezfaire capitalism a lesson for the early 1950s. This moment also coincided with the emergence of cultural studies and the understanding of culture as 'a whole way of life' shared with anthropology, which was directly reflected in the $A R^{\prime}$ 's editorial policy of bringing anonymous architectures to the fore under the banner of The Functional Tradition, while the urban environments visualised in the Townscape articles were proposed as settings for this new social order.

Within this framework, the reinterpretation of the Picturesque in urban terms carried enormous importance not simply for its visual appeal but for its deeper existential meaning. Hastings interpreted Emmanuel Swedenborg's idea of correspondences, which explained each branch of the arts as a form of revelation, understandable by analogy to another. He wrote that landscape was an 'art of OUT THERE that orientates and makes sense of all the arts. ${ }^{18}$ The Picturesque, 'a radical, anarchist and disorderly ideal ... [and] a tremendous event in the long apprenticeship of democracy', was the direct aesthetic outcome of a libertarian attitude to democracy. ${ }^{19}$ Through the recognition of a higher order of complexity in nature the debate on the Picturesque and the landscape garden served to illustrate harmonious ways of working with nature and to strengthen the connection between nature and humankind. ${ }^{20}$

In Uvedale Price's call for the irregular as an indispensable aspect of the picturesque Hastings read a democratisation of taste, one that allowed a radical departure from the norm:

In the picturesque we are offered-counting the Beautiful and the Sublime as first and second-a third, a radical, an anarchic kind of beauty: main stimuli, departures from the norm.... a beauty of character, of departure from rather than approach to the ideal... For the irregular makes every man ultimately his own judge on art. ${ }^{21}$

In the urban context such democratisation meant the coexistence of the new and the old, the modern and the traditional, and an eye that safeguarded the coexistence of difference which Hastings repeatedly emphasised throughout the lifespan of the Townscape campaigns, starting from his early articles 'Exterior Furnishing or Sharawaggi: The Art of Making Urban Landscape' (1944) and 'Townscape: A Plea for an English Visual Philosophy Founded on the True Rock of Sir Uvedale Price' (1949), and finishing with Civilia in 1971.

Hastings's choice of pseudonym was not accidental. According to Susan Lasdun and as confirmed by his daughter Priscilla Hastings, Ivor de Wolfe stood for ' $\%$, the world, the devil and the flesh. ${ }^{22}$ The world, the flesh and the devil is a quotation from the Anglican Book of Common Prayer that was adapted for the titles of a number of books and films during this period. Hastings added ' $I$ ' to the 'the world, the flesh and the devil' and switched the placing of the devil and the flesh. ${ }^{23}$ Chapters 
23, 24 and 25 of the manuscript are respectively entitled 'The World', 'The Devil' and 'The Flesh' under Part 8 which is called 'The Folly of Religion or The End of the World.' In these chapters Hastings reacts against institutionalised religion for suppressing the carnal and earthly, and separating the body from the soul. The pseudonym, I believe, symbolises this opposition and his nonconformist liberal religious views. Known for his wit, Hastings might also have intended an association with the surname of Elsie de Wolfe, the famous New York actress and interior decorator, or perhaps a subversive anthropomorphic wolf from a fairytale.

\section{After The Unnatural History of Man: Manplan (1969) and Civilia (1971)}

After the Townscape campaign reached its zenith with the special issues Outrage and CounterAttack, Hastings's editorial interventions in the $A R$ were largely restricted to writing independent articles. The practical application of Townscape in education was initiated by the joint effort of Gordon Cullen and Hugh Casson with architecture students of Birmingham and Bristol universities. ${ }^{24}$ By 1954 Townscape had spread around the world, evidenced by the way it was taken up by Kevin Lynch and his students at the Massachusetts Institute of technology (MIT). The influence spread in a range of literature in the United States including Jane Jacobs's The Death and Life of Great American Cities. ${ }^{25}$ The pedagogical success of Townscape allowed others and even outsiders to the $A R$, easily to follow in Cullen's footsteps to continue the series. $^{26}$
Hastings did not consider his mission accomplished, however, and September, 1969, marked a turning point. Reacting to the crisis in Britain, Hastings radically changed the $A R^{\prime} s$ look and called for comprehensive social reform more explicitly then before. Turning his back on sales success and the legacy of the $A R$ as the flagship of architectural journalism, he aimed to redefine British society through his Manplan special issues, launching an implicit attack on the conventions of architectural publishing in line with the increasing power of mass-circulation photo-journalism. Depicting people in dark atmospheres, shifting the focus from architecture to the users and severely questioning the heroic assumptions of Neo-Brutalism, Manplan was a call to reinvigorate architecture's social role in the light of Modernism's performance record.

Published in the form of visual essays followed by short provocative captions, these issues have been described as 'a tactile reminder of a time when magazines lived dangerously' and 'a perverse triumph of editorial conception and design'. ${ }^{27}$ Hastings commissioned prominent contemporary photographers such as Patrick Ward, lan Berry and Tony Ray-Jones to produce $15^{\prime \prime} \times 12^{\prime \prime}$ black and white prints. With as little text as possible, the first issue narrated a dark story of frustration on the faces of unemployed workers, the elderly in decaying housing, the bored crowds of public transport passengers and rebellious students. This was not the society that he described in his portrait of doom in The Unnatural History of Man but an equally disturbing vision of human failure in its place (figs 2, 3). 
Figure 2. 'Frustration', the first issue of Manplan (September, 1969), p. 175.

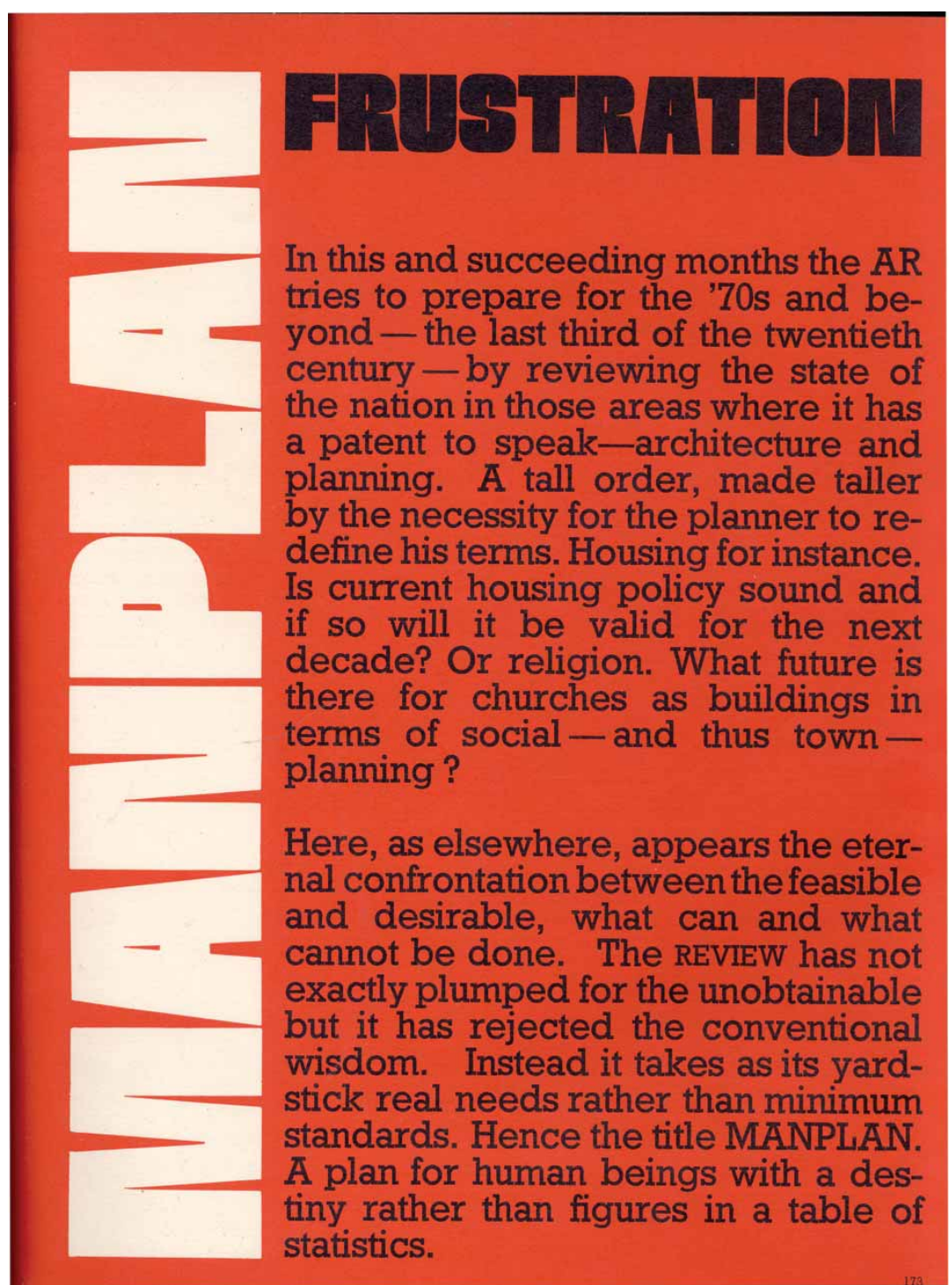




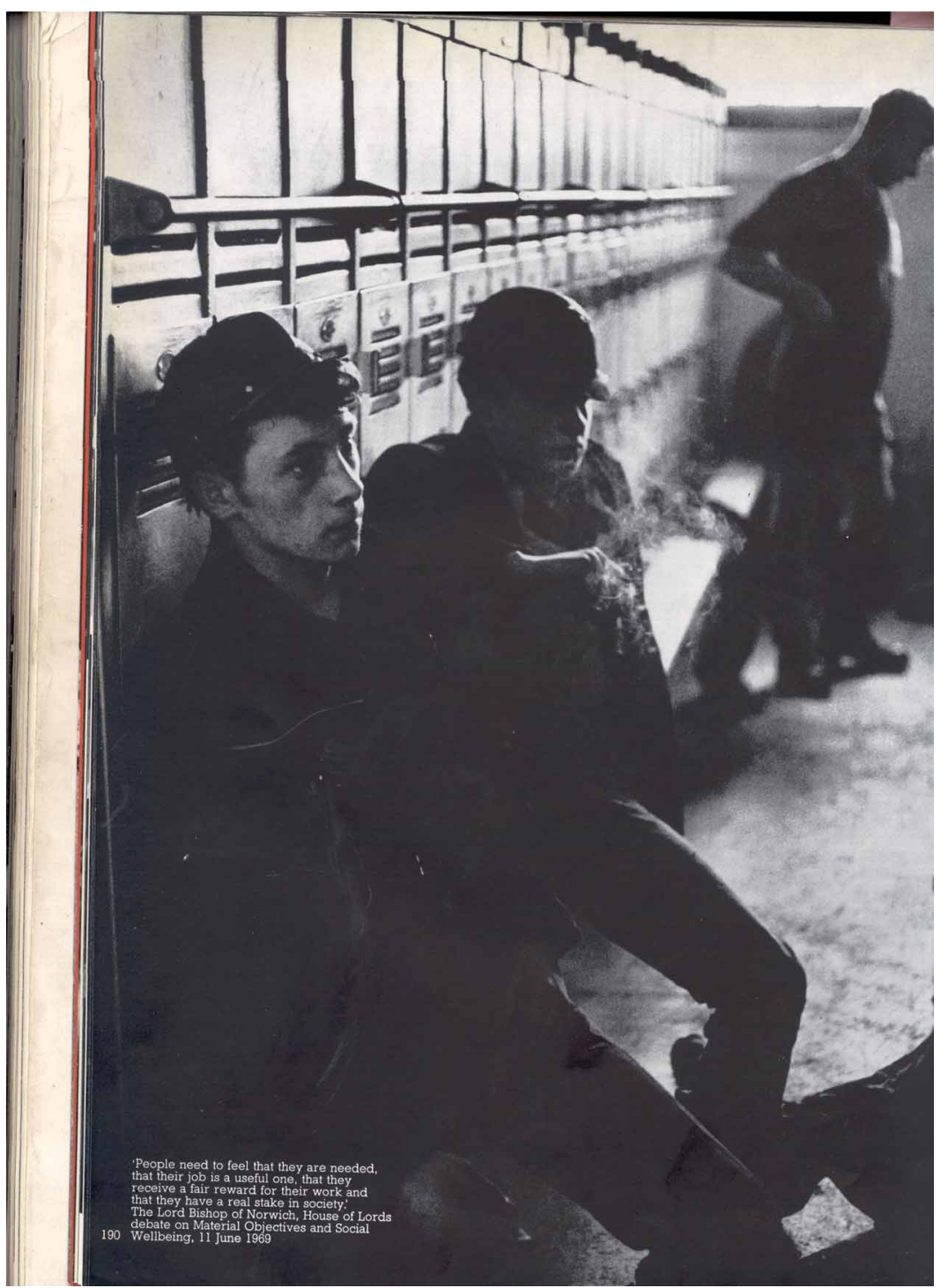

Figure 3. 'People need to know that they are needed', from 'Frustration', the first issue of Manplan (September, 1969), p. 190. 
In the following seven issues Hastings put industry, education, religion, healthcare and welfare, local government and housing in Britain under scrutiny with increasing polemical fervour. Coined in response to 'Non-Plan: An Experiment in Freedom' published six months earlier in the New Society by Reyner Banham, Peter Hall, Paul Barker and Cedric Price, Manplan protested against these authors' counter-cultural critique which demanded the lifting of planning restrictions to allow freedom of choice, decentralisation and dispersal. Paralleling the messages in his manuscript, Manplan argued that consumer culture and unlimited economic growth had already brought ruthless exploitation of resources and the destruction of the natural landscape during the economic crises of the 1960s. Although, in his memoirs, J. M Richards claims that the $A R$ went into a financial crisis in 1970 as a result of the Manplan series, figures from the Audit Bureau of Circulation ${ }^{28}$ show that several magazines experienced a slump in sales in this period, so the widespread legend of Manplan's threat of commercial disaster for the publishers was more probably a reaction against the unconventional behaviour of its angry old editor.

With the Manplan series abandoned on the insistence of his employee-colleagues, Hastings developed Civilia as an alternative vision of a new town that he hoped would create a convincing alternative to the three generations of low-density new towns (culminating in Milton Keynes) against which the $A R$ had campaigned vociferously ever since the war. Among Hastings's papers is a draft outline for a book named Townscape that he must have cancelled after the publication of Cullen's Townscape.
This draft, partially recycled in the text of The Italian Townscape (1963), a theoretical commentary on the photographic essay created by Hastings and his wife, also formed the basis for Civilia (Fig. 4). ${ }^{29}$ The Civilia book opened with a revised version of Hastings's essay 'The Theory of Contacts' originally submitted to CIAM in 1937 and then reworked as Chapter 14 of his manuscript. The essay aimed to interpret the city as a network of social and economic relationships embodied in the physical environment, in which architecture as such had a limited role. ${ }^{30}$ Civilia similarly emphasised the social role of human congestion as a natural result of the human tendency to socialise, calling for a celebration of high densities that would enable a diversity of social contacts instead of reducing their potential in the manner of low-density Garden City schemes.

Civilia opened with a foreword by lan Nairn, by then an internationally recognised journalist and author, and Hastings's introductory essay entitled 'Towards a Philosophy of the Environment'. Nairn pointed to the way that the 'affluent/possessive/ materialist/ society digs its own grave' as a result of suburban sprawl, although urbanised living could offer every comfort a citizen needed. ${ }^{31}$ Hastings questioned how planning could learn from economics in directing the benefits of such learning for what he called 'environmental reconstruction'. ${ }^{32}$ Against theories of decentralisation, Hastings argued that economic activity always favours dense and centralised urban forms.

The exposed rock surfaces and level changes of the North Nuneaton quarry which was the site selected for the project, contributed to a 'picturesque visual drama', offering a fantastic opportunity 


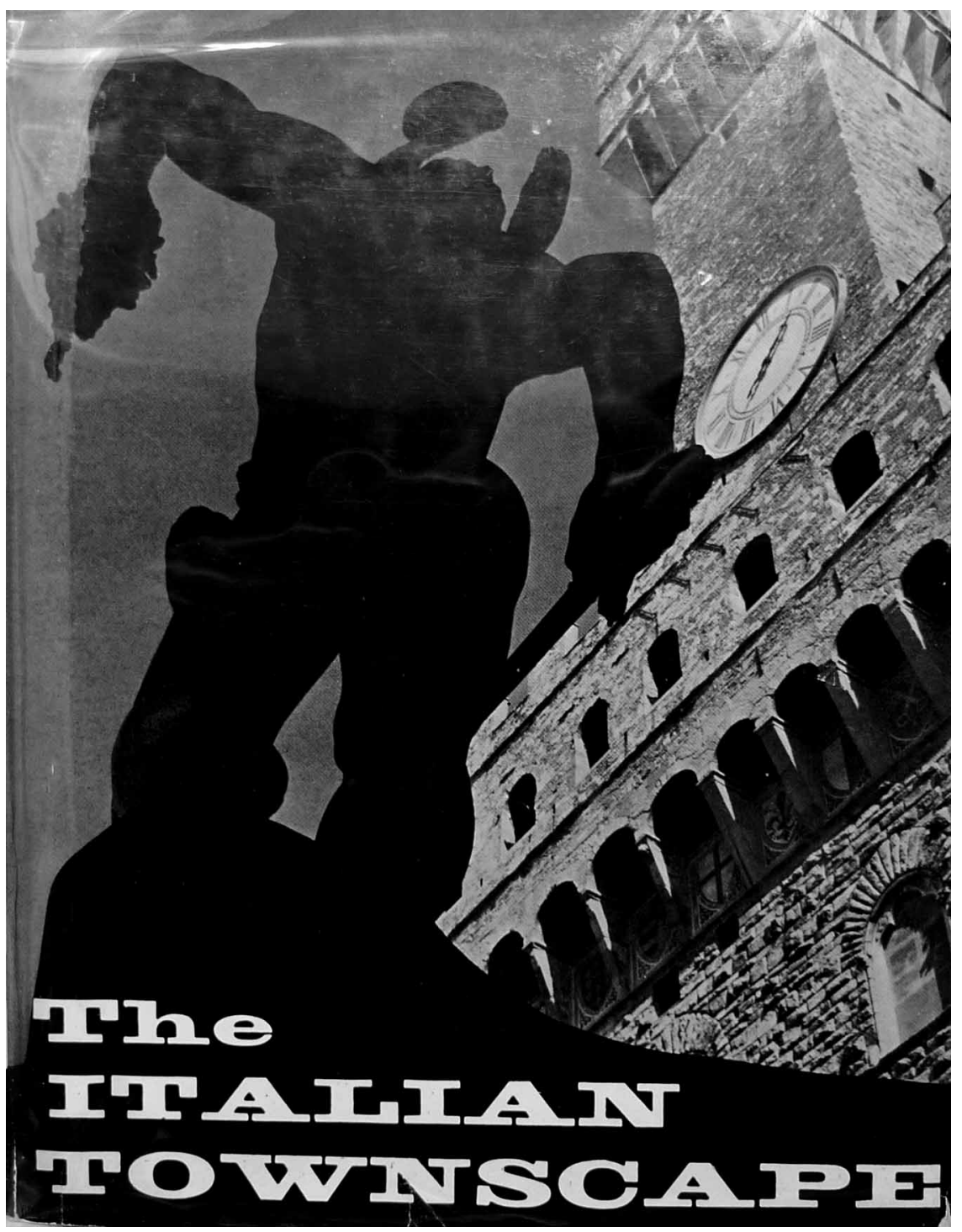

Figure 4. The

bookjacket of The

Italian Townscape. 
I, The World, The Devil and

The Flesh: Manplan, Civilia and $\mathrm{H}$. de C. Hastings Erdem Erten

Figure 5. Civilia cover page, The Architectural Review (June, 1971).

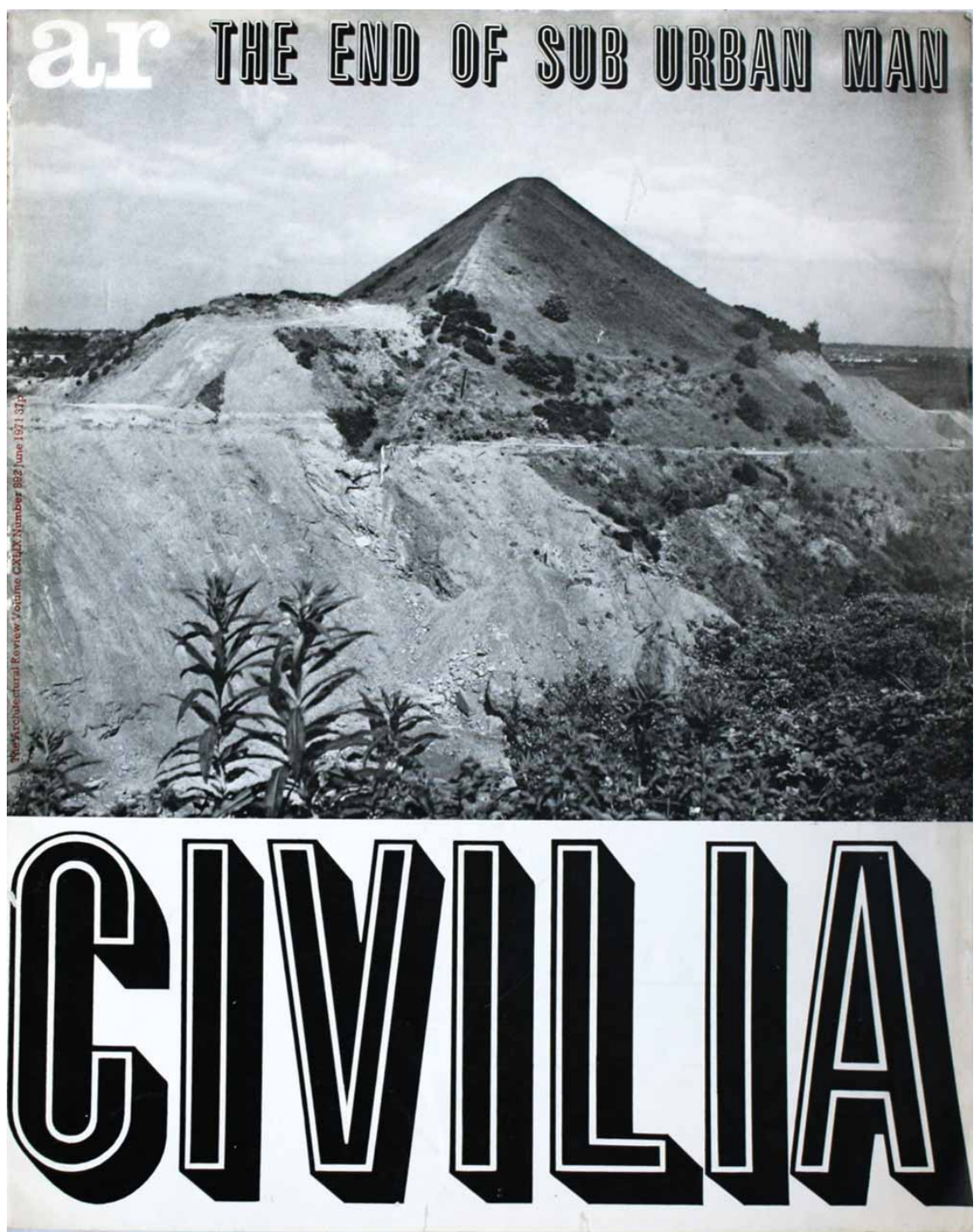




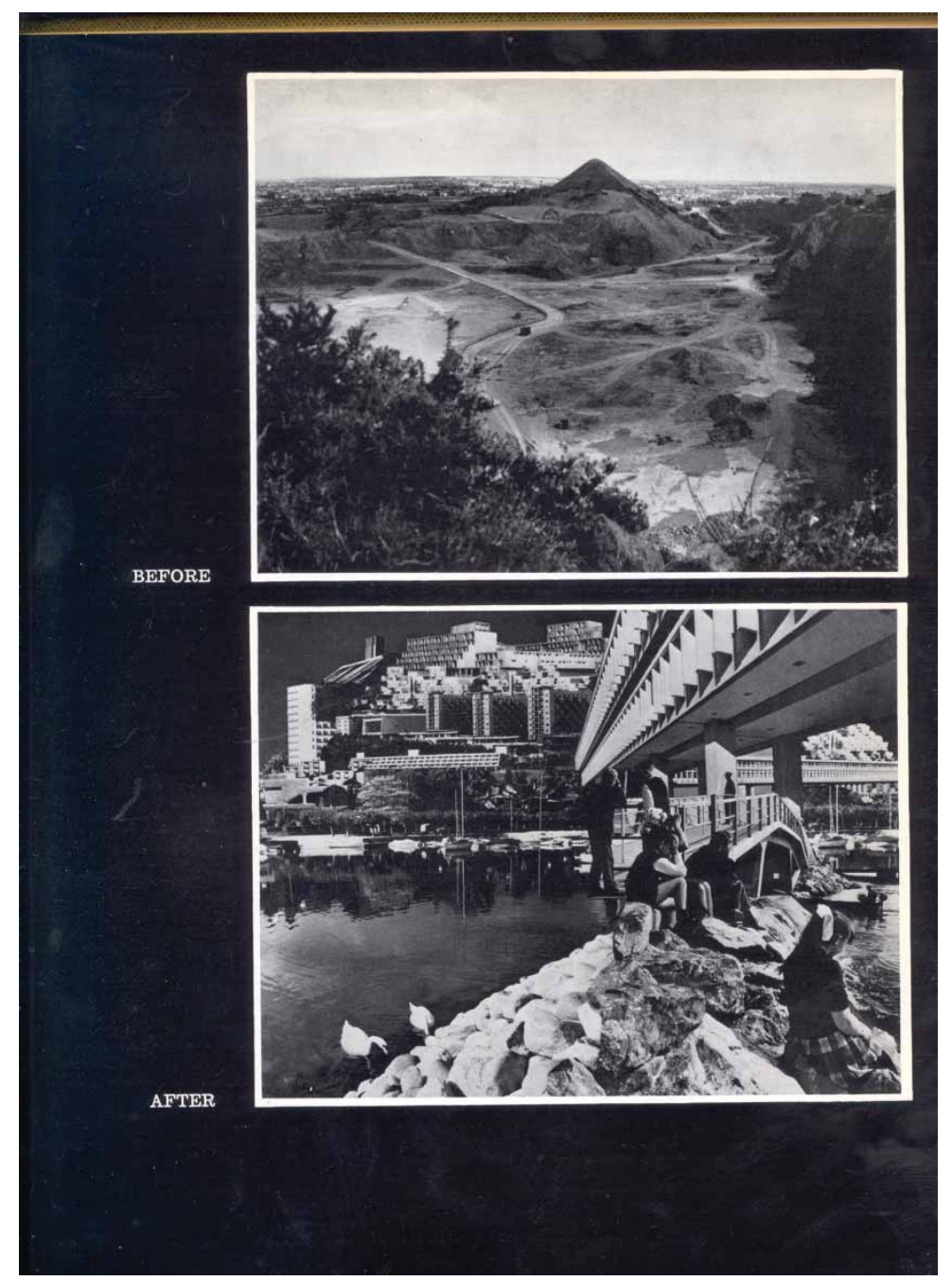

Figure 6. 'Before and after', Civilia, The End of Suburban Man: a Challenge to Semidetsia (London, Architectural Press, 1971), p. 49. 
for Hastings to make an environmental statement and realise the neo-romantic dream of making peace with nature (Fig. 5). The lake was linked to an existing canal that Hastings proposed should be used both for transport and leisure, picking up one of his favourite themes that the British canal system offered the potential for locating post-industrial leisure cities, while also offering an early example of the reclamation of ex-industrial sites. The photomontages produced by Kenneth Browne, Priscilla Baschieri-Salvadori (Hastings) and himself brought together images that spanned a range from Italian hill towns to recent New Brutalist architecture from the $A R^{\prime}$ 's photograph library (Fig. 6). For Hastings, collage and montage were techniques that democratised the art of townscape and that allowed everyone to have a say in the design of a city.

A reduced version of Civilia, published as the June, 1971, issue of the $A R$, was sent to a number of individuals for their comments after the book was announced by a press release. The comments were published in the Architects' Journal at the end of the month and subsequently provided lively material for the jacket flaps of the book, mixing praise with abuse. ${ }^{33}$ The seductive power of Civilia's visual language was in the eyes of some critics its ultimate weakness: Peter Cook called it a 'paste job' while Frederic Osborn, veteran advocate of low-density Garden Cities, referred to it as 'an odious damned lie'. ${ }^{34}$ The architect and planner Tom Hancock, the author of Peterborough's master plan, argued that if Civilia was an alternative city it required the creation of an alternative society. ${ }^{35}$ Hastings's choice of title for the published version of his manuscript, 'The Alternative Society:
Software for the Eighties' (1980), may have been a response to this comment. It was his final attempt to explain the long-pondered ideals that Civilia was meant to embody.

\section{After Ivor de Wolfe}

Urged by his campaigning spirit, Hastings wanted to reformulate the $A R^{\prime}$ 's environmental emphasis after disbanding the editorial board in 1971. Among his documents are memoranda to the board on a series of articles, taking as a springboard the January, 1972, issue of The Ecologist magazine (founded in 1970), and subtitled 'A Blueprint for Survival'. The distinguished group of scientists who signed The Ecologist's manifesto vindicated his prophecy of doom in The Unnatural History of Man by condemning 'the industrial way of life with its ethos of expansion'. ${ }^{36}$ The Ecologist demanded 'a new philosophy of life and a precise and comprehensive programme' so that human life on earth could be sustained and natural resources could be preserved. ${ }^{37}$ In this demand Hastings saw the possibility of an alternative science of compromise that had a bearing on the whole environment, one that he could finally support.

From Townscape to Civilia, Hastings steered the $A R$ to run campaigns which aimed to reconcile modernity and tradition by promoting a brand of neo-romanticism, arguing for its natural continuity with the national culture. If Civilia's offer of an alternative life appeared to achieve little in 1971, the fact that it could mobilise the people of Nuneaton in 2008 shows that Ivor de Wolfe's affair with the picturesque was about much more than just pictures. 


\section{Acknowledgements}

I would like to thank the anonymous referees, as well as Barnabas Calder, Gillian Darley and Steve Parnell for their comments on earlier versions of this paper, Alan Powers for his most valuable constructive criticism throughout its writing and Mathew Aitchison, John Macarthur and the Architecture History Theory Criticism Research Center of the University of Queensland for inviting me to present the first version of this paper at the Townscape Symposium in London, July, 2011.

\section{Notes and references}

1. Plans for the recycling plant were abandoned, after strong protests from the public, in January, 2009: see Claire Harrison, 'Dumped Forever', 16/01/2009; http://www.nuneaton-news.co.uk/News/DUMPEDFOREVER.htm

2. See Colin D. A. Boyne, 'H de C Hastings'; http://www. oxforddnb.com/

3. Susan Lasdun, 'H de C Reviewed',' The Architectural Review, 200 (September, 1996), pp. 68-72.

4. I was provided with a copy courtesy of Priscilla Hastings.

5. See Clive Bell, Art (London, Chatto \& Windus, 1931; 1st. ed. 1914).

6. Ivor de Wolfe (pseudonym of $\mathrm{H}$. de C. Hastings), The Unnatural History of Man; unpublished manuscript, p. 3.

7. Ibid.

8. Ibid., pp. 4-8 (italics mine).

9. Ibid., p. 577.

10. The Editors, 'The Second Half Century', The Architectural Review, 101 (January, 1947), p. 21.

11. In his interview tape with Susan Lasdun, Hastings states 'I have always been a Tory'. According to
Martin Wiener, Harold Macmillan, at the time a member of the House of Commons and prime minister in 1957, had insisted back in 1936 that 'Toryism has always been a form of paternal Socialism'. See Martin Wiener, English Culture and the Decline of the Industrial Spirit, 1850-1980 (Cambridge, Cambridge University Press, 1981), p. 108.

12. Julia Stapleton, Political Intellectuals and Public Identities in Britain since 1850 (Manchester, Manchester University Press, 2001), p. 119.

13. Hastings refers to Ernest Barker's 'Traditions of Civility' on p. 567 of his manuscript: see Ernest Barker, Traditions of Civility; Eight Essays (Cambridge, Cambridge University Press, 1948).

14. See J. M. Richards, 'A Theoretical Basis for Physical Planning', in The Architectural Review, 91 (February, 1942), p. 39.

15. See The Editors, 'The Second Half Century', op. cit.

16. See Dennis Dworkin, Cultural Marxism In Postwar Britain:History, The New Left, And The Origins of Cultural Studies (Durham, Duke University Press, 19), p. 32.

17. Dworkin's study establishes the active role of the Marxist historians group in this interpretation and its influence on the development of cultural studies. The group's defence of the progressive tradition was apparent in its involvement in the two major English historiographic controversies of the 1950s: the gentry's role in the English Revolution and the social consequences of the early Industrial Revolution. For more on this, see ibid., p. 19.

18. H. de C. Hastings, undated, 'Thoughts on Landscape and Democracy', p. 1. This document is an earlier draft for the 1949 Townscape article in Hastings's personal archive.

19. Hubert de Cronin Hastings, The Alternative Society: Software for the Nineteen-Eighties (London, David \& Charles Limited, 1980), p. 103 
I, The World, The Devil and The Flesh: Manplan, Civilia and $\mathrm{H}$. de C. Hastings Erdem Erten
20. See the article by Alan Powers in this Issue.

21. H. de C. Hastings, The Unnatural History of Man, op. cit., pp. 292-293.

22. See S. Lasdun, 'H de C Reviewed', op. cit.; Priscilla Hastings confirmed Lasdun's account in an interview with the Author in 2002.

23. In 1929 J.D. Bernal published a philosophical study, The World, The Flesh and the Devil: An Enquiry into the Future of the Three Enemies of the Rational Soul.' Bernal, a famous scientist, was a frequent contributor to architecture periodicals in 1946 on science and architecture, and worked at Birkbeck after 1938. The infernal triad is a recurring theme in the poetry of Spencer and Milton. See Patrick Cullen, Infernal Triad: The Flesh, the World, and the Devil in Spenser and Milton (Princeton, Princeton University Press, 1975).

24. Gordon Cullen, 'A scheme for the centre of Birmingham', in The Architectural Review, 109 (February, 1951), pp. 91-97. Later, Cullen produced two studies in collaboration with Bristol University: 'Dursley', in The Architectural Review, 120 (July, 1956), pp. 21-23 and 'Trowbridge', The Architectural Review, 123 (February, 1958), pp. 114-117. See also the correspondence section, entitled 'Townscape spreading to schools', in the September, 1956, Issue of the $A R$

25. See the articles by Alan Powers and Eric Ghenoiu in this Issue.

26. See the introductory article by Mathew Aitchison in this Issue.

27. See Simon Esterson, 'The $A R^{\prime}$ 's Manplan is a tactile reminder of a time when magazines lived danger- ously'; http://www.eyemagazine.com/feature.php? id $=119 \&$ fid

28. The Author wishes to thank Steve Parnell for this information.

29. 1.Theory of Contacts/a. Town, a complex of contacts/b. Town planning and the resolution of those/ c. Townscape and the art of interpreting that resolution in visual terms. 2. The English interpretation a.New Towns into Garden City/b. Absurdity of this solution/c. The fallacy of the small garden 3. The European tradition a. transition: the town wall/ b. invitation: the town gate/ c. introduction: narrow street/d. arrival: the town square/e. protection: the covered piazza.

30. See Reyner Banham, The New Brutalism: Ethic or Aesthetic? (London, The Architectural Press, 1966), pp. 74-75. On this, see also Matthew Aitchison, Visual Planning and Exterior Furnishing: A Critical History Of The Early Townscape Movement, 1930 To 1949 (PhD dissertation, University of Queensland, 2009), pp. 230-234.

31. See I. Nairn's Foreword in, Ivor de Wolfe, ed., Civilia: The End of Suburban Man (London, The Architectural Press, 1971), p. 3.

32. Ibid., p. 21.

33. See the brilliant recontextualisation of Civilia and Collage City by John Macarthur, The Picturesque: Architecture, Disgust and other Irregularities (London, Routledge, 2007), pp. 215-224.

34. See 'Civilia: the professionals comment', Architects' Journal, 153 (June, 1971), pp. 1452-1455.

35. Ibid

36. See The Ecologist, 2 (January, 1972), p. 2.

37. Ibid. 